\title{
Fatigue Properties of the Aluminium Alloy AW-5182 in dependence on Deformation
}

Jiri Sobotka, Pavel Solfronk, Michaela Kolnerova, David Korecek

Faculty of Mechanical Engineering, Technical University of Liberec. Studentská 1402/2, 46117 Liberec. Czech Republic. E-mail: jiri.sobotka@tul.cz, pavel.solfronk@tul.cz,michaela.kolnerova@tul.cz, david.korecek@tul.cz

Fatigue properties of the constructional materials belong among the very important material parameters, mainly because they are very closely related with the total fatigue life of the part. Knowledge of the boundary between limited and infinite (endurance) life represents a truly very important fatigue parameter. This paper deals with the influence of pre-deformation on aluminium alloy AW-5182 fatigue properties. These tests were performed under fully reversed harmonic cycle $(\mathrm{max} / \mathrm{min}$ stress ratio $R=\mathbf{- 1})$. As a major aim there was determination of socalled S-N curves (stress vs. number of cycles) and their mathematical description by the Basquin's equation via fatigue strenght coefficient $\sigma_{f}^{\prime}[\mathrm{MPa}$ ] and fatigue strength exponent $b$ [1]. Measured $S-N$ curves gave a basic overview about the basic pre-deformation influence on the alluminium alloy $\mathrm{AW}$ - 5182 fatigue properties.

Keywords: Fatigue, Alluminium Alloy AW-5182, Basquin's Equation, Endurance Limit, S-N Curves

\section{Acknowledgement}

This publication was written at the Technical University of Liberec (TUL) as part of the Student Grant Contest "SGS 21122" with the support of the Specific University Research Grant, as provided by the Ministry of Education, Youth and Sports of the Czech Republic in the year 2017.

\section{References}

[1] HERTZBERG, R.W. (1996). Deformation and Fracture Mechanics of Engineering Materials, pp. 556 - 570. John Wiley \& Sons, New York.

[2] RUZICKA, M., HANKE, M., ROST, M. (1989). Dynamická pevnost a životnost, pp. 26 - 34. CVUT Publisher, Prague.

[3] POLMEAR, I. (2006) Ligth Alloy-From traditional Alloys to Nanocrystals, pp. 97-115. Butterworth-Heinemann. Oxford

[4] DAVIES, G. (2003) Materials for Automobile Bodies. pp. 87-91. Butterworth-Heinemann, Oxford.

[5] SCHIJVE, J. (2009) Fatigue of structures and materials. pp. 25-34. Kluwer Academic Publishers. Dordrecht.

[6] ASM HANDBOOK. (2000) Volume 8 - Mechanical Testing and Evaluation. pp. 104-130.ASM International. Materials Park.

[7] SMALlman, R.E., NGAN, A.H.W. (2007) Physical Metallurgy and Advanced Materials. pp. 150-163. Butterworth-Heinemann. Oxford

[8] KUCHARIKOVA, L. et al. (2017). High-cycles Fatigue of Different Casted Secondary Aluminium Alloys. pp. 756-761. Manufacturing Technology, Volume 17.

[9] NOVÝ, F. et al. (2016) Fatigue Durability of Ductile Iron in Very-High-Cycle Region. pp. 406-410. Manufacturing Technology, Volume 16.

[10] VAŠKO, A. et al. (201) Microstructure and Fatigue Properties of Nodular Cast Iron at Low Frequency Cyclic Loading. pp. 1188-1193. Manufacturing Technology, Volume 16. 